\title{
The Construction of Expatriate Identity: A Critical Discourse Analysis on "Indonesia Expat" Magazine
}

\author{
Vivian Graciela Chertian ${ }^{1}$, Esther Kuntjara ${ }^{2}$ \\ English Department, Faculty of Letters, Petra Christian University, \\ Siwalankerto 121-131, Surabaya 60236, INDONESIA \\ E-mail: vivian.gchertian@gmail.com ${ }^{1}$; estherk@ petra.ac.id ${ }^{2}$
}

\begin{abstract}
This thesis is a study on the construction of expatriate's identity in Indonesia Expat magazine. The purpose of this study is to find how the expatriate's identity is constructed in Indonesia Expat. In this study, the theory used was van Dijk's (2015) critical discourse analysis. The data were parts of texts taken from Meet the Expat and Info for Expat columns in Indonesia Expat magazine. The writers took a descriptive qualitative approach in this study. According to the findings, there were five identities constructed about the expatriates: skillful, successful, wealthy, healthy, and caring. These identities were constructed by utilizing background, details, graphics, and word choice to generate particular interpretations.
\end{abstract}

Keywords: Critical discourse analysis, expatriate, identity, elite

\section{INTRODUCTION}

Abundant natural and human resources, along with vibrant culture, attracts foreigners to conduct business in Indonesia. Several of them decided to stay in Indonesia to work, and they are called "expatriates". This term has several meanings, for instance, people who live outside their home country, or "someone who takes up an international assignment for their current employer", and s/he is offered financial incentives, for instance higher salaries for accommodation, moving allowance, private transportation, insurance, and even children's school fees (Fechter, 2007, p.2). According to Fechter (2007), in Indonesia itself, the label 'expatriate' is frequently referring to corporate Euro-American residents living in luxury and leisure.

Adjusting life in a multicultural society is not an easy feat to accomplish for expatriates in Indonesia, especially considering that they may have hardships that cannot be covered just by material incentives. Thus, they need guides and information about life in Indonesia. One of the few magazines written in English providing information for expatriates in Indonesia is Indonesia Expat, a bi-weekly magazine mainly targeting expatriates who live and work in Indonesia. The magazine consists of feature stories, "meet the expat" interviews, business profiles, news articles, and helpful information for expats ("Indonesia Expat media kit," 2019). It also contains advertisements promoting various accommodations and facilities.

As one of the few resources providing information about Indonesia for expatriates in English, Indonesia Expat possesses a certain control over media, particularly in discourses mainly targeting expatriates. The form of control may involve the decision of identities in particular events or accomplishment of certain actions by the social group involved (van Dijk, 2015) using media. The extent to which a certain individual/group holds power/control over another individual/group regarding their identities can be identified using critical discourse analysis (CDA).

CDA is an analysis which sees how social power is produced in a text in a social/political context. It also focuses on how discourse structures establish, legitimate, or 
reproduce certain dominance in a society. Van Dijk's (2015) CDA points out that discourse has three dimensions; one of them includes text. According to van Dijk (as cited in Eriyanto, 2012), a text is divided into three levels which support each other: macrostructure, superstructure, and microstructure - each containing smaller parts, such as sentence structure or word choice, to influence the reader's opinion, create support, or reinforce an idea.

Since CDA is capable of seeing the extent of control of an individual/group over another, it is also possible to use CDA to see what kind of individual/group identity was formed through the existing control. Identity is a mental constructs formed by shared mental representations about one's self and others (van Dijk as cited in de Fina, 2019). It can be formed by the information that they retrieve from various sources in their daily life, including media. Therefore, media has certain control over the mental representations of an individual/group, thus having an influence over the individual/group's identity construction.

In Indonesia Expat magazine, there are two columns mainly featuring expatriates, which are Meet the Expat, which profiles an expatriate from different countries in each issue, and Info for Expats, which provides helpful tips and information for expatriates. In this research, we use van Dijk's CDA to analyse the textual structure of these articles, retrieved from the digital version of Indonesia Expat magazine, to see how the identity of expatriates is constructed from the selected texts.

Through this research, we hope to provide more insight regarding the use of CDA to analyse how a text constructs the identity of a certain group in the society. Furthermore, we also hope to contribute more information in studies about expatriates, especially in Indonesia, and media discourse for further research in this field.

\section{REVIEW OF RELATED LITERATURE}

\section{Critical Discourse Analysis}

Critical discourse analysis (CDA) is an analysis method which assesses how social power and/or abuse are produced in a text or talk in a social or political context. It also focuses on how discourse structures establish, legitimate, or reproduce of certain dominance in a society (van Dijk, 2015). Moreover, it focuses on identity expression in public discourse, such as political speeches, public documents, newspaper articles, etc. CDA also pays more attention to language structures than to interaction. This is done by analysing the topics of a text, the discourse strategies, and the linguistic forms used to create and transform identities and convey them (de Fina, 2019).

According to van Dijk (as cited in Eriyanto, 2012), a text consists of structures supporting each other, divided into three levels: macrostructure, superstructure, and microstructures. Moreover, according to Eriyanto (2012, pp.229-274), different discourse structure have different functions. The first discourse structure is macrostructure, the main idea of a text which shows the dominant, central, and most important concept of an article. The second discourse structure is the superstructure, the schematic element in discourse. A text or discourse usually has a schema which shows prioritized parts in conveying an information. By utilizing a certain schema, an author of article constructs the public's understanding of a particular event the way the author wants. The third discourse structure is microstructure, classified into semantic, syntactic, stylistic, and rhetoric aspects. Semantic aspect determines the direction where the readers' perceptions are carried and serve as control of how much information is given to the audience that best benefits a certain party. Syntactic aspects mainly deal with how an author positions somebody in a discourse or use discourse to explain the 
Chertian, et al:: The Construction of Expatriate Identity: A Critical Discourse Analysis on "Indonesia Expat" Magazine

relationship between one event and another. Stylistic aspect shows the author uses certain words to influence the mental models of text recipients. Lastly, rhetorical aspect is used to emphasize certain parts in the text to control the text reader's interests into focusing on the important part of the text.

\section{Identity}

Identity is described as a mental construct formed by shared mental representations (ideology, knowledge, attitude, emotion, norms, and values) about one's self and others (van Dijk as cited in de Fina, 2019). It is seen as a social construction of an individual/group's membership to other social groups/categories (de Fina, 2019). A process of identification with the groups to which someone belongs is an important element that connects him/her to groups. It also tells a group or individual who they are. An identity is thus "the product of a process of social categorization and of identification with the groups we belong to, which we then characterize as part of ourselves" (Spears, 2011, p.203).

According to de Fina (2019), there are three traits of having an identity. Firstly, having an identity means "being cast into a category related to certain characteristics" (de Fina, 2019, p.3). This means identities are connected to social categories based on the individual or group's association with certain properties (traits) and activities. Second, associations between identities and social categories can vary widely depending on the participants and social contexts. Third, identities are occasioned, i.e. they are "invoked, made relevant, and negotiated within particular discursive exchanges, so they should not be seen as 'belonging' to the individual or the group" (de Fina, 2019, p.3). Identities are also seen as fluid, crossing, decentring, diasporadic and hybrid (Benwell \& Stokoe, 2006, p.22), and aspects which forms identities can be learned through different discourse practices implemented within institutions, one of it including mass media (de Fina, 2019, p.4).

\section{METHODS}

This study is a descriptive qualitative study in form of critical discourse analysis, with the data taken from Indonesia Expat magazine issues 250-255 (published 20 November 2019-25 February 2020). To collect the data, we gathered Meet the Expat and Info for Expat articles from the selected magazine issues. In this study, we analyzed the data using van Dijk's (2015) critical discourse analysis.

There were several steps that we took to collect the data. Firstly, we read the whole articles of Meet the Expat and Info for Expats sections from Indonesia Expat magazine issues 250-255. Afterwards, we highlighted the sentences which were deemed able to reflect the construction of expatriate identity. The identity constructed was also identified from the data taken. After the data were collected, the textual structures used were interpreted, and how they constructed the expatriates' identity was analyzed.

\section{FINDINGS AND DISCUSSION}

From Indonesia Expat magazine issues 250-255, there was a total of three Meet the Expat articles and three Info for Expats articles from which the data were retrieved. Based on the six data sources collected, we found that there are five notable identities constructed about expatriates, i.e. skillful, successful, wealthy, healthy, and caring.

Firstly, expatriates' identity is constructed as skillful. According to Merriam-Webster Online Dictionary ("Skillful | Definition of skillful by Merriam-Webster," 2020), skillful means somebody possesses/displays the ability to use his/her knowledge effectively, or do something 
competently. This identity is mainly constructed through the use of background, details, and word choices, as demonstrated in the data below.

Table 4.1 Data demonstrating expatriate's skillful identity

\begin{tabular}{|c|c|}
\hline $\begin{array}{c}\text { I've always wanted to live in a developing country because I } \\
\text { learned how economics could impact a developing country when I did } \\
\text { my Master's, and Indonesia fit just right. }\end{array}$ & Ref. Code \\
\hline $\begin{array}{c}\text { It was fascinating for a fresh graduate like me to see how } \\
\text { powerful the whole start-up ecosystem was; it's grown at a speed of } \\
\text { 30-40 percent every month. }\end{array}$ & $\mathrm{ME} / 250 / 002$ \\
\hline $\begin{array}{c}\text { DJ El Didion will Get You Hot and Steamy on Bali's } \\
\text { Dancefloors }\end{array}$ & $\mathrm{ME} / 251 / 001$ \\
\hline $\begin{array}{c}\text { When he is behind the turntables somewhere in a local club, it's } \\
100 \text { percent guaranteed the night is going to be hot and steamy on the } \\
\text { dancefloor. }\end{array}$ & $\mathrm{ME} / 251 / 003$ \\
\hline $\begin{array}{c}\text { I've also had a record label specialized in electro music in } \\
\text { France. Back then, I performed in many festivals, mostly in Europe } \\
\text { and Asia. }\end{array}$ & $\mathrm{ME} / 251 / 005$ \\
\hline $\begin{array}{c}\text { I previously was focused on Indonesia for Bosch Rexroth. My } \\
\text { expertise in Tightening Systems for the last 30 odd years has now } \\
\text { made me very busy in helping other countries in the region. }\end{array}$ & $\mathrm{ME} / 255 / 005$ \\
\hline
\end{tabular}

In these data, the reference code was made up of alphabets ME/IE to indicate the type of article (Meet the Expat or Info for Expat respectively), the number of magazine issue from which the datum is taken (issue 250, 251, etc.), and the number of datum. Also, we intentionally bolded the letters in the table to show the words or phrases that we think play a role in the construction of expatriates' identity.

Firstly, the expatriates' skillful identity is reflected from their educational background, first mentioned in ME/250/001. The expatriate is asked about why he chose Indonesia as a place to work, which serves as a background for further questions regarding his career. In his answer, the expatriate mentions that he attended graduate school and specifically mentioned learning economics. Moreover, by making a judgment of which country would be the most fit to apply what he had learnt in his education, he showed his being intelligent to an extent. This intelligence is supported by how he displayed the ability to calculate the growth of the start-up ecosystem (ME/250/002). Despite him being a fresh graduate, he defines the growth in detailed statistical numbers. These data show how the expatriate has a good education background and specialized knowledge in economics. These contribute to his skill, and at the same time, demonstrate how he can apply that skill in real business context.

Secondly, the skillful identity is constructed from the details and word choice regarding the expatriates' expertise at work. For example the use of the words "hot" and "steamy" in the statement "DJ El Didion will Get You Hot and Steamy on Bali's Dancefloors". These words emphasized the expatriate's skill in his field of work. The adjective "hot" defines something filled with passionate excitement, while the adjective "steamy" is used when a passionate activity is involved. These words, combined with the words "club", "night", and "dancefloor", display the detail on how the expatriate featured is working in a nightclub. In this context, it is implied that the expatriate DJ is very good at his job and that he is able to make the situation in the nightclub more passionate. In addition, the words used in the title, hot and steamy, are repeated inside the article to emphasize the DJ's ability further (ME/251/003). Another example is when the expatriate mentioned a detail on how he has his own specialized record label in his home country, France. This shows a certain level of acknowledgment of his skill in his own 
Chertian, et al:: The Construction of Expatriate Identity: A Critical Discourse Analysis on "Indonesia Expat" Magazine

country, which is then carried to various countries in Europe and Asia, including Indonesia (ME/251/005). These capabilities set the expatriate apart as a specialist in his field, showing his skillful identity. The expatriate's skillful identity is also shown through the expatriate's long working experience. For instance, an expatriate mentioned in detail that he worked in Bosch Rexroth for 30 years

(ME/255/005). Bosch Rexroth was a large company based in Germany specializing in machine technologies and had been running for approximately 200 years. Being able to work for a long run in a renowned company shows that this expatriate has the professional quality needed for his line of work, further emphasizing the "skillful" identity.

The data above have highlighted the construction of expatriates' skillful identity. By showing the expatriates' exceptional skills, it is implied that expatriates perform excellently in their field of work, thus creating an implication that they are successful in their career. This eventually creates another identity for expatriates, i.e. successful.

Table 4.2 Data demonstrating expatriate's successful identity

\begin{tabular}{|c|c|}
\hline \multicolumn{1}{|c|}{ Data } & Ref. Code \\
\hline $\begin{array}{c}\text { Creating designs and helping people make their house a home } \\
\text { is personally rewarding and satisfying, compared to becoming a } \\
\text { reseller. }\end{array}$ & ME/250/004 \\
\hline $\begin{array}{c}\text { I love seeing any of my contributions to a small platform } \\
\text { become big and impactful. }\end{array}$ & $\mathrm{ME} / 250 / 009$ \\
\hline $\begin{array}{c}\text { Steph is the founder and owner of a Los Angeles based real } \\
\text { estate development and holding business. }\end{array}$ & $\mathrm{IE} / 250 / 001$ \\
\hline $\begin{array}{c}\text { He started as a fashion designer, but is now a well-known star } \\
\text { of the Bali nightlife scene. }\end{array}$ & $\mathrm{ME} / 251 / 002$ \\
\hline $\begin{array}{c}\text { I then went on to play semi-professional for Nuneaton } \\
\text { Borough, Hinckley Athletic, Racing Club Warwick, and Chelmley } \\
\text { Town. Not to mention, I played for several top teams in the Sunday } \\
\text { Leagues, then played across Europe in the likes of Belgium, } \\
\text { Germany, Italy, and even Turkey. }\end{array}$ & $\mathrm{ME} / 255 / 006$ \\
\hline $\begin{array}{c}\text { I also had the chance to coach my U9 team called Arden } \\
\text { Forest at Wembley } \\
\text { Stadium, in front of over 70,000 fans before the Aston Villa V }\end{array}$ & $\mathrm{ME} / 255 / 007$ \\
$\begin{array}{l}\text { Bolton Wonderers FA Cup Semi-Final in 2000, in which we beat } \\
\text { Bolton Academy 2-0. }\end{array}$ & \\
\hline $\begin{array}{c}\text { Moving to Indonesia while running a business is a life- } \\
\text { changing adventure. Doing it all with family in tow is a unique and } \\
\text { special kind of challenge. We spoke with three local expat parents } \\
\text { about what makes running a business while raising a family in } \\
\text { Indonesia worth it. }\end{array}$ & $\mathrm{IE} / 250 / 007$ \\
\hline $\begin{array}{c}\text { This accomplished French musician tells Indonesia Expat } \\
\text { what it takes to be up almost every night to entertain the very } \\
\text { demanding crowds of Bali's party people. }\end{array}$ & \\
\hline
\end{tabular}

The successful identity is constructed mainly through the use of background, details, and particular word choice.

The construction of successful identity starts with details on how the expatriates' success stems from their passion in doing their job. When someone has passion in doing his/her job, s/he will have more energy and motivation to work, and even inspire others through his/her 
work. These can contribute to someone's success (Anderson, 2013). This can be seen when an expatriate comments about his job as an interior furniture designer. He uses the word "rewarding" and "satisfying" (ME/250/004) to define his job. This means the expatriate feels very happy and content in doing his job. Moreover, he mentions how he loves seeing his works bring a big change (ME/250/009). This reflects the expatriate's strong feeling of wanting to give an impact through his work. It is also an implication of how being able to contribute through his work gives him the rewarding and satisfying feeling in doing his job. These word choices construct the idea that expatriates' passion towards their job bear successful results at work.

Aside from passion of working in their respective jobs, expatriates are shown to be successful through details regarding their business. One example is a statement revealing an expatriate as a founder and owner of a real estate business in Los Angeles (IE/250/001). As the center of film and television industry, added with other business opportunities provided in a metropolitan city, Los Angeles has a massive population growth. Therefore, real estate business becomes one of the most popular and profit-generating business in Los Angeles (Leusin, 2019). The detail of how the featured expatriate starts and owns a real estate business in a city with huge prospect in real estate shows the expatriate's success. Another example shows the expatriate's success through the word choice. An expatriate is described as a well-known star in Bali (ME/251/002). The word "star", according to Oxford Online Dictionary, defines a very famous entertainer. The paired use of the words "well-known" and "star" creates a significance on the expatriate's fame. The fame is associated with the word "successful" itself, which is used to describe how somebody accomplished an aim or result, or achieved fame, wealth, or social status ("Successful | Meaning of successful by Lexico," n.d.). This emphasizes the expatriate's identity as successful.

Expatriates are also shown to be successful not only in professional careers, but also semiprofessional ones. For instance, an expatriate talking about his semi-professional football career (ME/255/006-007) is particularly specific in mentioning the clubs for whom he has played, including his experience in playing for several teams in England and playing across Europe. Moreover, he includes his experience as a coach of a team playing a match at Wembley Stadium. Wembley Stadium is well-known as the home stadium of the England national football team (Lewis, 2016), as well as the largest football stadium in the UK and second-largest stadium in Europe. This stadium is also the venue where FA Cup Finals, one of the most attended domestic football events in the world, is conducted. The expatriate also mentions Aston Villa, one of the clubs competing in the Premier League, the top tier of English football league system. The excessive amount of details and mentions of renowned names in the football community are inserted to depict his long record of experience and also success in the semi-professional field, reinforcing the successful identity.

Interestingly, the writers of the magazine articles (hereby called the authors) themselves also support the expatriates' success stories, further showing their role in constructing the expatriates' successful identity. This can be seen notably from the introductory sentences in several articles. For example, in IE/250/007, the author mentions how expatriates with families moving to Indonesia while running a business face a challenging adventure. The author relies mostly on word choice to construct the expatriates' successful identity in this datum. By using the word "adventure", the author wants to show how becoming an expatriate means taking risks in exchange for an unusual yet exciting experience. The author also uses the word "challenge", which can mean a situation that tests someone's abilities ("Challenge | Meaning of challenge by Lexico," n.d.), to emphasize how hard it is going to be for an expatriate to work while managing a family. At the end, however, the author points out how the featured expatriates think that running a business while raising a family in Indonesia is worth the while. This implies that the expatriates see working while raising a family in Indonesia as something sufficiently good or 
Chertian, et al:: The Construction of Expatriate Identity: A Critical Discourse Analysis on "Indonesia Expat" Magazine

interesting. Furthermore, it implies how these expatriates overcome the difficulties of working in a foreign country while taking care of their family with their abilities. By overcoming the difficulties, they demonstrate how they can turn a difficult situation into something good for them. By highlighting the expatriates' success in conquering their difficulties, the author constructs the expatriates' successful identity.

Another example is in one of the sentences written in the introductory paragraph in an article of Meet the Expat. The author mentions the featured expatriate as an accomplished musician (ME/251/004). The adjective "accomplished" is used to define someone who is highly trained or skilled in a particular activity. Using this word in the beginning of the text gives a powerful start and emphasis on how the expatriate is successful before the author goes deeper into the details of the expatriates' skills and accomplishments, therefore reinforcing the successful identity constructed.

Exceptional skills and following success will then contribute to the expatriates' possession of a huge sum of money. This leads to the expatriates' wealthy identity.

Table 4.3 Data demonstrating expatriates' wealthy identity

\begin{tabular}{|c|c|}
\hline Data & Ref. Code \\
\hline $\begin{array}{c}\text { I've been doing this for two years, so yes, I have a KITAS } \\
\text { specially for DJs, valid for six months, which costs me about Rp20/22 } \\
\text { million. }\end{array}$ & ME/251/006 \\
\hline $\begin{array}{c}\text { Therefore, to set up a foreign company, a PT PMA, you will } \\
\text { need to pay up Rp 2.5 billion (less than US\$ 200.000) as capital. }\end{array}$ & IE/253/001 \\
\hline $\begin{array}{c}\text { "Our advice is to use all the intelligence you can get, even if it } \\
\text { means higher costs and slower progress in the beginning." }\end{array}$ & IE/255/002 \\
\hline $\begin{array}{c}\text { Travelling often, Steph had plenty of international options to } \\
\text { compare, ... }\end{array}$ & IE/250/002 \\
\hline $\begin{array}{l}\text { "We have a photographer on retainer to capture special } \\
\text { masseuse on regular rotation, private swim coach, dressage lessons } \\
\text { for my three-year-old who likes horses, and I'm free to explore classes } \\
\text { like breath-work or pottery that I'd never been able to do in LA } \\
\text { because of my workload and traffic." }\end{array}$ & \\
\hline
\end{tabular}

To show the wealth of the expatriates, details and graphics are utilized in the texts. Graphics in this context refer to the display of numbers, and they are usually displayed to create a sense of precision and accuracy of a particular statement.

The expatriates' wealthy identity is first demonstrated in a business perspective. This is done through the insertion of details regarding expatriates' necessary budget for work. The nominal of money displayed reaches millions to billions, emphasizing on the large amount of money needed for work permit and a company set-up capital (ME/251/009 and IE/253/002). Meanwhile in IE/255/002, the author gives advice for the readers not to hesitate in spending higher costs when planning to start a business. This indirectly implies that expatriates have a significant amount of wealth which allows them to spend more cost in exchange for something beneficial for their business.

The expatriates' wealthy identity is also shown through details on the expatriates' luxurious lifestyle. For instance, an expatriate is shown to be "travelling often". From using these words only, the reader gets knowledge of the expatriate's high travelling frequency (IE/250/002). This expatriate has a real estate business in Los Angeles. This statement of 
travelling often implies how the expatriate, at the very minimum, flies frequently back and forth Indonesia and Los Angeles for her business. A one-way flight from Indonesia to Los Angeles can cost more than 10 million rupiahs on average. Moreover, this expatriate is previously mentioned as engaging in real estate business, which deals with a huge amount of investment and money. It is evident that the expatriate possesses a large amount of wealth.

The expatriate's wealth is further illustrated to the readers by the details given in $\mathrm{IE} / 250 / 013$. It is mentioned that the expatriate has a photographer, swim coach, and masseuse, who receive salary regularly. Firstly, the photographer mentioned is on retainer, meaning the photographer is paid in advance so that s/he can work immediately on call. According to SalaryExpert ("Photographer salary Indonesia - SalaryExpert," 2020), in Indonesia, a photographer's average hourly rate is approximately 90.000 rupiahs. Paying in advance may increase the amount of pay for the photographer, especially when the photographer is required to capture both simple and special moments in the expatriates' family (working frequent hours). Meanwhile, swim coach can receive an average annual salary of approximately 105 million rupiahs ("Swim coach salary Indonesia - SalaryExpert," 2020), and masseuse approximately 153 million rupiahs per year

("Masseur/masseuse salary Indonesia - SalaryExpert," 2020). Not to mention that the expatriate is capable of providing her son a dressage lesson, which will require approximately 125 million rupiahs in a year for the dressage trainer's average base salary ("Dressage \& stunt horse trainer salary Indonesia - SalaryExpert," 2020). Considering the amount of expenses spent, it is clear that the expatriates live a luxurious lifestyle, emphasizing expatriates' wealthy identity.

So far, expatriates are implied to be very hard-working, which resulted in their success and wealth. There may be a rising concern of expatriates overworking to receive such success and wealth, but that does not seem to be the case. In the text, the expatriates are depicted as having a healthy lifestyle and can manage both their physical and mental health well. This leads to the expatriates' identity of being healthy. This identity is formed through details and different word choices. The following data are implications of expatriates being both physically and mentally healthy.

Table 4.4 Data demonstrating expatriates' healthy identity

\begin{tabular}{|c|c|}
\hline $\begin{array}{c}\text { Data } \\
\text { A complex surgery didn't even stop him from stepping } \\
\text { onto the field! }\end{array}$ & Ref. Code \\
\hline $\begin{array}{c}\text { Eventually I moved to Jakarta. Here, I happen to play for } \\
\text { BuGils. I find it amazing that at the age of 62, I can still play and } \\
\text { I'm enjoying it more than ever. }\end{array}$ & $\mathrm{ME} / 255 / 008$ \\
\hline $\begin{array}{c}\text { For a parent of a large family and head of a medium-size } \\
\text { private company based in LA, Bali is both a refuge and a chance } \\
\text { to live our true values. }\end{array}$ & $\mathrm{IE} / 250 / 009$ \\
\hline $\begin{array}{c}\text { "Finding my groove, disconnecting from my former } \\
\text { professional life, and finding a tribe of parents that get us } \\
\text { happened so quickly that I forgot it was my number one worry. }\end{array}$ & $\mathrm{IE} / 250 / 015$ \\
\hline $\begin{array}{c}\text { It becomes an intimate opportunity to get to know a new } \\
\text { culture, new people and a new environment. It is simultaneously a } \\
\text { source of insights, ideas, and frustrations, from new habits and } \\
\text { expectations to local rules and regulations. }\end{array}$ & $\mathrm{IE} / 250 / 016$ \\
\hline $\begin{array}{c}\text { Indonesia Expat had the fantastic opportunity to be } \\
\text { embraced by Robin's positive outlook in life and welcoming a } \\
\text { new chapter in Indonesia. }\end{array}$ & $\mathrm{ME} / 255 / 004$ \\
\hline
\end{tabular}


Chertian, et al.: The Construction of Expatriate Identity: A Critical Discourse Analysis on "Indonesia Expat" Magazine

The first evidence of the expatriates' healthy identity is the details talking about the expatriates' physical endurance. For example, an expatriate is said to have undergone a complex surgery, but continues doing sport. The expatriate, even though he was already at an old age, still continues playing football for a local football club (ME/255/003\&008). This depicts expatriates as physically fit, contributing to their healthy identity. The expatriates are also shown to be mentally healthy as well, though it is more implicitly stated.

The implication is seen in the comments on how the expatriates' lives in Indonesia have provided them a more laid-back and relaxed environment. However, in order to get a grasp on how these statements proved that the expatriates are mentally healthy, we have to first observe these statements in the context of expatriates living a busy life.

In IE/250/009, for example, the busy life is shown in the contrast of nuance in the nouns mentioned in one sentence, i.e. "medium-size private company based in LA" and "Bali is a refuge". The phrase "medium-size private company based in LA" pictures a business conducted in one of the liveliest and busiest cities in the world. On the contrary, the word "refuge" pictures a place for finding safety and shelter. Using these contrasting nouns, the expatriate conveys how Bali becomes a place where the expatriate can stop from her quickpaced, busy life. Another example to support this is in a statement where a different expatriate mentions how her life has changed since she stayed in Bali (IE/250/015). The expatriate states that she finds her groove and disconnects from her professional life when living in Bali. This means she finds her new established routine in Bali where she can live at her own relaxed pace. Also, even though it is not explicitly mentioned what kind of professional job she has ever had, it can be deduced that living in Bali has allowed her to get a change of pace from focusing on a professional career to doing something she enjoys. These comments show how the expatriates long for a relaxed and laid-back routine, implying that they have a busy life.

From the interpretation above, the implication that the expatriates have to bear with a fully-packed, business-oriented routine is clear. Assuming this is the case, that would mean the expatriates have to deal with taking risks or encountering problems in their daily life. This also means the expatriates are coping with daily stress, which, in long term, would be harmful for the expatriates' mental health. The expatriates, however, are capable of adjusting themselves in their new environment (Indonesia) and viewing their lives in Indonesia as something capable of de-stressing them. In a mental health perspective, this capability demonstrates their low vulnerability to stress, i.e. capability to manage themselves in challenging situations and have a positive view in adapting to their current situation (Kaufman, 2018).

The expatriates also display the capability of having positive thoughts and feelings, which are also traits of being mentally healthy according to Kaufman (2018). Instead of focusing on the struggle of adapting to their new environment in Indonesia, the expatriates view their expatriation as an opportunity for them to gain new knowledge or insights (IE/250/016). By using words such as "sources of insights, ideas" or "gives us a new lens to see ourselves" when talking about their expatriation, the expatriates show that they can overcome the challenges they faced when adapting with their new life and turn them into something positive. This is supported even by the author's comment, in which the author admits that even Indonesia Expat editorial was influenced by the expatriate's positive outlook in life (see ME/255/004). This optimism, as well as openmindedness, are traits of people with positive mental health, thus contributing to expatriates' healthy identity.

The expatriate's identities so far depicted them as people who are very capable of doing things at work, and their lives revolve around working, though balanced with keeping 
themselves healthy. It might seem as if these expatriates have no time to care about anything else other than work and personal health. However, this is proven to be false, since Indonesia Expat magazine displays the expatriates' caring side in their personal lives, not only to their children, but also the people around them. This caring identity is seen in the data below.

Table 4.5 Data demonstrating expatriates' caring identity

\begin{tabular}{|c|c|}
\hline Data & Ref. Code \\
\hline $\begin{array}{c}\text { From the moment we saw the Green School, we were } \\
\text { enchanted with our kids growing up without walls, surrounded by } \\
\text { nature. }\end{array}$ & IE/250/003 \\
\hline $\begin{array}{c}\text { For more expats, it becomes a reasonable option in Indonesia. } \\
\text { It can directly make the idea of a more personal time alongside kids } \\
\text { and business a reality. }\end{array}$ & IE/250/012 \\
\hline $\begin{array}{c}\text { Hannah is crafting her life with considerably more family time } \\
\text { by combining the two together directly. “...It's wonderful that my } \\
\text { business involves my children because I couldn't run a guide for } \\
\text { families in Bali without them!” }\end{array}$ & IE/250/011 \\
\hline $\begin{array}{c}\text { Marta's vision is “to make this world a more compassionate, } \\
\text { mindful and heart-connected place, one person at a time." }\end{array}$ & IE/250/004 \\
\hline $\begin{array}{c}\text { Marta recently started hosting mama and child retreats in } \\
\text { addition to her existing healing and transformation classes. }\end{array}$ & IE/250/014 \\
\hline $\begin{array}{c}\text { Indonesians are very skillful when it comes to handicrafts and } \\
\text { carving wood, rattan, and other fantastic materials from the jungle. }\end{array}$ & $\mathrm{ME} / 250 / 003$ \\
\hline $\begin{array}{c}\text { I also found Indonesians ramah. They don't expect anything } \\
\text { in return; they're genuine and very welcoming with whomever they } \\
\text { meet, regardless if they're meeting for the first time. }\end{array}$ & $\mathrm{ME} / 250 / 006$ \\
\hline $\begin{array}{c}\text { My family and I cannot thank Doctor Adi enough for the way } \\
\text { he treated me, along with his professionalism - I will always be } \\
\text { indebted to him. }\end{array}$ & $\mathrm{ME} / 255 / 010$ \\
\hline
\end{tabular}

Expatriates' caring identity, particularly as parents, can be seen from several data. In IE/250/003, a pair of parent expatriates describes how they feel enchanted upon finding a school suitable for their children. They use the words "enchanted" and "growing up without walls, surrounded by nature". "Enchanted", as defined in Oxford Dictionary, means "filled with delight". These expatriates previously came from a metropolitan city, therefore they should have lived in a place with a small amount of green area and less fresh air. Moreover, the expatriate mentions how the children will be "growing up without walls" as they enroll in Green School, which implies how living in a metropolitan city has limited the children's activity outdoors in a green space. Successfully finding an environment where the children can get fresher air for their health shows how the expatriate parents put an effort for their children to be healthy and live in a good environment, and in a place where they can grow well. In this part, the word choice and detail used show the caring aspect of an expatriate parent.

The parent expatriates' caring identity are shown further by the mentions of children and/or balancing family with work. For instance, there is a statement that more family time while conducting business could be a reality in Indonesia for expatriates (IE/250/012). This implies that when working in their home countries, the expatriates have less family time, especially with their children, because their daily routine is packed with work. However, expatriating to Indonesia makes family time more possible, and so, some expatriates choose to expatriate in order to make more time with their children. This shows how expatriates cared about keeping a good relationship with their family. 
Chertian, et al:: The Construction of Expatriate Identity: A Critical Discourse Analysis on "Indonesia Expat" Magazine

Expatriates are also shown as caring by complimenting their children's contribution, exemplified in a comment where an expatriate gives credits to her children's involvement in her business (IE/250/011). The expatriate has a business of providing guides for families in Bali. To be a successful guide, she needs to have a certain amount of knowledge regarding living or activities in Bali for families. In order to get plenty of knowledge and experience about it, it would be best for her to experience living with a family in Bali firsthand. Through her personal experience, she can build her business and let her children participate in it, and at the same time, letting her have more family time. Her willingness to manage her time and business in a way that she can have family time shows how she cares about her family, especially her children, to an extent. In addition, by stating how she can not run a guide for families in Bali without her children, the expatriate gives credits and acknowledgment to her children. This also shows how the parent expatriate cares for her children enough to give them the compliment they deserved.

Expatriates are depicted as caring not only to their family, but also to the well-being of people, even in business. Two data give the readers details on an expatriate's business, i.e. the expatriate's vision for a more compassionate world (IE/250/004). The use of the word "compassionate" displays how the expatriate is concerned about the well-being and feeling of the people around her. In order to fulfill this vision, the expatriate starts a retreat for mother and child in her business. A retreat's main purpose is to withdraw to a quiet place to obtain peace of mind ("Retreat | Meaning of retreat by Lexico," 2020). This retreat also provides bonding time between parents and child, and specifically in this case, mother and child. By starting these retreats, the expatriate shows how she also cares about the relationship between mother and child, along with their mental health. Being a mother herself, providing this detail to be featured in the article allows her to display how she can relate to other mothers, and how she cares about the mothers and their children out there, in accordance to her vision. This then contributes to the formation of the caring identity.

In addition to that, expatriates showed how caring they are by giving compliments about Indonesia, particularly about Indonesians' friendliness or skills. Even though the expatriate talked about Indonesians in those compliments, the inclusion of those sentences inside the text plays a role in constructing the expatriates' caring identity. The first example is an expatriate's compliment about an Indonesian's skill (ME/250/003). In the compliment, the expatriate uses the adverb "very" and "extremely", which emphasizes the adjective which follows, i.e. skillful. The expatriate mentions the Indonesian's specific parts of expertise (handicrafts, carving, product design, graphic design). By using those words and details as the compliment, the expatriate acknowledges the creativity and crafting skills of the people of their current country of residence, i.e. Indonesia. It also allows the expatriates to show their appreciation towards Indonesians. They also show appreciation towards Indonesians by highlighting their friendliness and generosity even though the expatriates have just met them for the first time (ME/250/006). Another expatriate even uses a strong word, "indebted", to show deep respect to a person who has helped him (ME/255/010). These acknowledgments demonstrate expatriates' mutual respect and kindness, thus generating the expatriates' caring identity.

These five identities constitute a bigger collective identity, i.e. "elite". Elite is "a select group that is superior in terms of ability or qualities to the rest of a group/society", or "a group/class of people seen as having the most power and influence in a society, especially on account of their wealth/privilege" ("Elite | Meaning of elite by Lexico," n.d.). Indonesia Expat magazine demonstrates the skillful and caring abilities, successful and healthy qualities, and the wealth and privilege expatriates have as foreigners. These actually point out the characteristics of elites, making Indonesia Expat construct expatriates' identities as elites in the Indonesian society. 
As of 2018, the number of foreign workers registered by the Ministry of Labor itself only contributed $0.04 \%$ of the whole population in Indonesia ("Inilah jumlah tenaga kerja asing di Indonesia dibanding beberapa negara tahun 2018 - Databoks," 2019). This means the number of expatriates in Indonesia is relatively small. Inside this small group are expatriates coming from different countries, which, altogether, form an exclusive group in the Indonesian society. This is in congruence with how elites are heterogeneous, yet unified, and came from an exclusive layer in the society (Sutisna, 2001).

Additionally, these expatriates also possess a group consciousness, another trait of elites. They share a similar background as people who came from outside Indonesia, loyally belong to their own country group (smaller group within the expatriates themselves), and shared a common interest (conducting business, sticking to one's origin country's culture, etc.) (Sutisna, 2001). This group consciousness seems to exist in the society, as Fechter (2007) exemplified that an expatriate attending a gathering for expatriates of a different country would be given the side-eye treatment or deemed not loyal to their own home country. Another example is when an expatriate wears batik to a formal gathering for expatriates and viewed as having "gone native", as if those expatriates no longer belonged to the expatriate group as a whole. This strengthens how expatriates position themselves as elites in the Indonesian society, even among fellow expatriates.

\section{CONCLUSION}

It can be concluded that expatriates' identities are constructed as positive identities, and the identities found, i.e. skillful, successful, wealthy, healthy, and caring, resulted in expatriates' collective identity as elites in the Indonesian society. From this conclusion, we realized that this identity construction was an evidence of a distinguished grouping in the society, particularly between Indonesians and expatriates. It also implied a significant social and economy difference between Indonesians and expatriates.

An interesting aspect was that Indonesia Expat magazine had a foreigner (expatriate) as the chief editorial advisor. Since the chief editorial advisor was part of the expatriate group, he possessed a certain consciousness that he had to display the positive aspect of his group in the society as he had the power to do so. Also, by positioning expatriates as elites, Indonesia Expat emphasizes that the expatriates deserve all the riches and privileges they possess as a compensation for being placed in the "troublesome" Indonesia (not having certain food, modes of transportation, or facilities they can find easily in their home country). Meanwhile, the name of the authors in the Meet the Expat and Info for Expats articles analyzed are not written, with an exception of one expatriate contributor (author). This could be done to emphasize expatriates' significance and contribution and allow the articles to highlight the figure of expatriates.

In this study, we mainly elaborated the expatriates' identity construction analysis in textual level and only briefly discussed about elitism in expatriates. Further studies might want to look deeper into identity construction in social cognition and social context level, and into a deeper aspect of elitism. Also, future studies by other researchers may take different perspectives, such as how the expatriates' identities were constructed from an expatriate reader's perspective or how Indonesians' identities were constructed from an Indonesian reader's perspective. Other aspects in this magazine, such as photos and advertisements, are also available to analyze in future studies. 
Chertian, et al:: The Construction of Expatriate Identity: A Critical Discourse Analysis on "Indonesia Expat" Magazine

\section{REFERENCES}

Anderson, A. R. (2013). Does being passionate about the work you do increase your chance of success? | Forbes. Retrieved May 3, 2020, from https://www.forbes.com/sites/amyanderson/2013/03/27/does-being-passionate-aboutthework-you-do-increase-your-chance-of-success/\#a725e7d6809f

Benwell, B., \& Stokoe, E. (2006). Theorising discourse and identity. In Discourse and Identity (pp. 17-47). Edinburgh: Edinburgh University Press Ltd.

Challenge | Meaning of challenge by Lexico. (n.d.). Retrieved February 18, 2020, from https://www.lexico.com/definition/challenge

De Fina, A. (2019). Discourse and Identity. The Encyclopedia of Applied Linguistics, 1-8. https://doi.org/10.1002/9781405198431.wbeal0326.pub2

Dressage \& stunt horse trainer salary Indonesia - SalaryExpert. (2020). Retrieved May 9, 2020, from https://www.salaryexpert.com/salary/job/dressage-and-stunt-horse-trainer/indonesia

Elite | Meaning of elite by Lexico. (n.d.). Retrieved April 10, 2020, from https://www.lexico.com/definition/elite

Eriyanto. (2012). Analisis wacana: Pengantar analisis teks media. Yogyakarta: LKiS.

Expatriate | Meaning of expatriate by Lexico. (n.d.). Retrieved February 18, 2020, from https://www.lexico.com/definition/expatriate

Fechter, A.-M. (2007). Transnational lives: Expatriates in Indonesia. https://doi.org/10.5622/illinois/9780252041846.003.0001

Indonesia Expat media kit. (2019). Retrieved February 18, 2020, from https://indonesiaexpat.biz/wp-content/uploads/2019/08/ie-media-kit-2019-2020-5.pdf

Inilah jumlah tenaga kerja asing di Indonesia dibanding beberapa negara tahun 2018 - Databoks. (2019). Retrieved May 23, 2020, from

https://databoks.katadata.co.id/datapublish/2019/04/10/inilah-jumlah-tenaga-kerja-asingdiindonesia-dibanding-beberapa-negara-tahun-2018

Kaufman, S. B. (2018). Do you have a healthy personality? - Scientific American blog network. Retrieved May 20, 2020, from https://blogs.scientificamerican.com/beautiful-minds/doyouhave-a-healthy-personality/

Leusin, Y. (2019). Where to invest in the Los Angeles real estate market 2019. Retrieved April 27, 2020, from https://www.mashvisor.com/blog/invest-los-angeles-real-estatemarket2019/

Lewis, R. (2016). Wembley Stadium. In Encyclopaedia Britannica. Retrieved from https://www.britannica.com/place/Wembley-Stadium

Masseur/masseuse salary Indonesia - SalaryExpert. (2020). Retrieved May 9, 2020, from https://www.salaryexpert.com/salary/job/masseur-masseuse/indonesia

Maulana, I. (2013). Struktur wacana rubrik Bale Bandung dalam majalah Mangle (analisis wacana kritis model Teun A. van Dijk). Lokabasa, 4(2), 136-144.

Photographer salary Indonesia - SalaryExpert. (2020). Retrieved May 9, 2020, from https://www.salaryexpert.com/salary/job/photographer/indonesia

Retreat | Meaning of retreat by Lexico. (2020). 
Skillful | Definition of skillful by Merriam-Webster. (2020). Retrieved June 5, 2020, from https://www.merriam-webster.com/dictionary/skillful

Successful | Meaning of successful by Lexico. (n.d.). Retrieved February 18, 2020, from https://www.lexico.com/definition/successful

Sutisna, A. (2001). Pluralisme dan elitisme. Retrieved from https://www.academia.edu/9587104/Pluralisme_dan_Elitisme

Swim coach salary Indonesia - SalaryExpert. (2020). Retrieved May 9, 2020, from https://www.salaryexpert.com/salary/job/swim-coach/indonesia

Van Dijk, T. A. (2015). Critical discourse analysis. In D. Tannen, H. E. Hamilton, \& D. Schiffrin (Eds.), The Handbook of Discourse Analysis: Vol. I (2nd ed., pp. 466-485). Wiley-Blackwell.

Yaqin, M. Z. N. (2017). Representasi ideologi dalam struktur wacana "Kata Hari Ini." LiNGUA, 12(2), 99-109. Retrieved from http://ejournal.uinmalang.ac.id/index.php/humbud/article/view/4056/pdf 